\title{
Dietary Fiber and Chronic Disease ${ }^{1}$
}

\author{
Wendy J. Dahl ${ }^{2}$
}

Dietary fibers are carbohydrates that are not digestible-they are what is left over after we digest proteins, fats, starches, and sugars from plant-based foods. Plant foods contain dietary fiber, and sources include whole grains, legumes, fruits, vegetables, nuts, and seeds.

When we eat foods containing dietary fiber, the fiber moves unchanged through the stomach and small intestine to the colon (large intestine). Once in the colon, fiber works to promote laxation and prevent constipation. However, dietary fiber has many more positive effects on health. This publication describes the relationships between dietary fiber and prevention and treatment of chronic disease.

\section{How does fiber work to prevent disease?}

Dietary fiber is broken down by bacteria in the colon, a process called "fermentation." Fermentation of fiber supports the growth of a healthy balance of good bacteria in the colon. In addition, the process of fermentation produces substances that promote health of the colon and body as a whole (Dahl et al. 2017).

\section{What chronic diseases might dietary fiber help to prevent?}

Consuming a diet higher in dietary fiber is linked to a decreased risk of developing cardiovascular (heart) disease (Threapleton et al. 2013), type 2 diabetes (Yao et al. 2014), bowel disease (Liu et al. 2015), and chronic kidney disease
(Xu et al. 2014). Each additional $5 \mathrm{~g}$ of fiber per day (e.g. $1 / 2$ cup oatmeal or 1 large potato with skin) decreases risk of developing chronic kidney disease by more than $10 \%$. Higher dietary fiber intakes are also linked to survival. Each additional $10 \mathrm{~g}$ of fiber per day (e.g. 11/2 cups of bran flakes or $3 / 4$ cup of lentils) reduces risk of death by $10 \%$ (Yang et al. 2015). Higher intakes of dietary fiber are also related to a lower body weight (Shay et al. 2012).

\section{How does dietary fiber help with chronic disease?}

Diets high in dietary fiber promote better health in a number of ways (Dahl and Stewart 2015). A higher dietary fiber intake will help to bulk the stool and promote regularity. Some dietary fibers, such as those found in oatmeal and legumes, can help to reduce total blood cholesterol and LDL (bad) cholesterol; lower LDL cholesterol helps to reduce your risk of heart disease. Dietary fiber may also help reduce blood glucose and blood insulin levels, which is helpful for the prevention and management of type 2 diabetes. Fermentation of dietary fiber produces substances known as "short chain fatty acids" that may help reduce inflammation that contributes to most chronic diseases (Dahl et al. 2016). This reduced inflammation related to consuming dietary fiber is thought to be especially important for those with chronic kidney disease (Krishnamurthy et al. 2012).

1. This document is FSHN18-11, one of a series of the Food Science and Human Nutrition Department, UF/IFAS Extension. Original publication date August 2018. Visit the EDIS website at http://edis.ifas.ufl.edu.

2. Wendy J. Dahl, associate professor, Department of Food Science and Human Nutrition; UF/IFAS Extension, Gainesville, FL 32611.

The Institute of Food and Agricultural Sciences (IFAS) is an Equal Opportunity Institution authorized to provide research, educational information and other services only to individuals and institutions that function with non-discrimination with respect to race, creed, color, religion, age, disability, sex, sexual orientation, marital status, national origin, political opinions or affiliations. For more information on obtaining other UF/IFAS Extension publications, contact your county's UF/IFAS Extension office. 


\section{How can I increase my dietary fiber intake?}

There are many ways to increase dietary fiber intake. Here are a few suggestions:

- Choose whole grain bread, cereals, and pastas instead of refined grain foods.

- Double vegetable servings at lunch and dinner.

- Choose whole fruit, nuts, and seeds as snacks.

- For some meals, replace meat as the main course with beans, peas, or lentils.

Dietary fiber intake can also be increased by choosing foods with added fiber, such as breakfast cereals and breads with added brans or hull fibers (e.g. wheat bran, oat bran, pea hull, and oat hull)

\section{Summary}

Dietary fiber is helpful in the prevention and management of many chronic diseases. Choosing foods higher in dietary fiber, such as whole grains, legumes, fruits, vegetables, nuts, and seeds, is a positive step towards good health.

\section{References}

Dahl, W. J., and M. L. Stewart. 2015. "Position of the Academy of Nutrition and Dietetics: Health Implications of Dietary Fiber." J Acad Nutr Diet. 115(11): 1861-70. doi: 10.1016/j.jand.2015.09.003.

Dahl, W. J., N. C. Agro, Eliasson A. M., Mialki K. L., Olivera J. D., C. T. Rusch, and C. N. Young. 2016. "Health benefits of fiber fermentation." Journal of the American College of Nutrition.

Dahl, Wendy J., Nicole C. Agro, Åsa M. Eliasson, Kaley L. Mialki, Joseph D. Olivera, Carley T. Rusch, and Carly N. Young. 2017. "Health Benefits of Fiber Fermentation." Journal of the American College of Nutrition. 1-10. doi: 10.1080/07315724.2016.1188737.

Krishnamurthy, V. M., G. Wei, B. C. Baird, M. Murtaugh, M. B. Chonchol, K. L. Raphael, T. Greene, and S. Beddhu. 2012. "High dietary fiber intake is associated with decreased inflammation and all-cause mortality in patients with chronic kidney disease." Kidney Int. 81(3): 300-6. doi: 10.1038/ki.2011.355.

Liu, X., Y. Wu, F. Li, and D. Zhang. 2015. "Dietary fiber intake reduces risk of inflammatory bowel disease: result from a meta-analysis." Nutr Res. 35(9): 753-8. doi: 10.1016/j.nutres.2015.05.021.

Shay, C. M., L. Van Horn, J. Stamler, A. R. Dyer, I. J. Brown, Q. Chan, K. Miura, L. Zhao, N. Okuda, M. L. Daviglus, and P. Elliott. 2012. "Food and nutrient intakes and their associations with lower BMI in middle-aged US adults: the International Study of Macro-/Micronutrients and Blood Pressure (INTERMAP)." Am J Clin Nutr. 96(3): 483-91. doi: 10.3945/ajcn.111.025056.

Threapleton, D. E., D. C. Greenwood, C. E. Evans, C. L. Cleghorn, C. Nykjaer, C. Woodhead, J. E. Cade, C. P. Gale, and V. J. Burley. 2013. "Dietary fibre intake and risk of cardiovascular disease: systematic review and metaanalysis." BMJ. 347: f6879. doi: 10.1136/bmj.f6879.

Xu, H., X. Huang, U. Riserus, V. M. Krishnamurthy, T. Cederholm, J. Arnlov, B. Lindholm, P. Sjogren, and J. J. Carrero. 2014. "Dietary fiber, kidney function, inflammation, and mortality risk." Clin J Am Soc Nephrol. 9(12): 2104-10. doi: $10.2215 /$ cjn.02260314.

Yang, Y., L. G. Zhao, Q. J. Wu, X. Ma, and Y. B. Xiang. 2015. "Association between dietary fiber and lower risk of all-cause mortality: a meta-analysis of cohort studies." Am J Epidemiol. 181(2): 83-91. doi: 10.1093/aje/kwu257.

Yao, B., H. Fang, W. Xu, Y. Yan, H. Xu, Y. Liu, M. Mo, H. Zhang, and Y. Zhao. 2014. "Dietary fiber intake and risk of type 2 diabetes: a dose-response analysis of prospective studies." Eur J Epidemiol. 29(2): 79-88. doi: 10.1007/ s10654-013-9876-x. 